\title{
What happens at the gap between knowledge and practice? Spaces of encounter and misencounter between environmental scientists and local people
}

\author{
Anne H. Toomev ${ }^{1,2}$
}

\begin{abstract}
Researchers studying processes of global environmental change are increasingly interested in their work having impacts that go beyond academia to influence policy and management. Recent scholarship in the conservation sciences has pointed to the existence of a research-action gap and has proposed various solutions for overcoming it. However, most of these studies have been limited to the spaces of dissemination, where the science has already been done and is then to be passed over to users of the information. Much less attention has been paid to encounters that occur between scientists and nonscientists during the practice of doing scientific research, especially in situations that include everyday roles of labor and styles of communication (i.e., fieldwork). This paper builds on theories of contact that have examined encounters and relations between different groups and cultures in diverse settings. I use quantitative and qualitative evidence from Madidi National Park, Bolivia, including an analysis of past research in the protected area, as well as interviews $(N=137)$ and workshops and focus groups $(N=12)$ with local inhabitants, scientists, and park guards. The study demonstrates the significance of currently unacknowledged or undervalued components of the research-action gap, such as power, respect, and recognition, to develop a relational and reciprocal notion of impact. I explain why, within such spaces of encounter or misencounter between scientists and local people, knowledge can be exchanged or hidden away, worldviews can be expanded or further entrenched, and scientific research can be welcomed or rejected.
\end{abstract}

Key Words: encounter; impact agenda; knowing-doing gap; knowledge-exchange; research-action

\section{INTRODUCTION}

\section{Minding the gaps in conservation science}

Recent trends in academia incentivize science to have greater relevance to society, and the engagement of scientists with the public (and vice versa) is becoming a common occurrence (Bäckstrand 2003, Nowotny et al. 2006, Pain et al. 2011, Whitmarsh et al. 2011). This is particularly pertinent in the conservation sciences, where the idea that science should provide practical knowledge to be acted upon spurred the creation of the "mission-driven" discipline of conservation biology in the 1980s, which has since expanded to include sustainability science, citizen science, transdisciplinarity, and boundary work (Soulé 1985, Clark and Dickson 2003, Boreux et al. 2009, Meine 2010, Lang et al. 2012, Shirk et al. 2012, von Heland et al. 2014). Scholarship in this field has also pointed to the existence of a "knowing-doing" or "research-implementation" gap, which argues that although much conservation research has implications for management, it often has little direct effect on the environmental problems it seeks to address (Knight et al. 2008, Arlettaz et al. 2010, Hulme 2014, Walsh et al. 2015, Gossa et al. 2015).

Much of the literature pertaining to the gap stresses the importance of the communication, dissemination, and implementation that should occur once the science is already done (Milner-Gulland et al. 2010, Weichselgartner and Kasperson 2010, Walsh et al. 2015). For example, Arlettaz et al. (2010:840) present a diagram in which they depict the researchimplementation gap as something that happens at the end of conventional scientific production, before the "extra tasks of conservationists" begin. This focus on the products of conservation science has gained increasing visibility through papers and journals arguing for "evidence-based conservation" (Sutherland et al. 2004, Pullin and Knight 2009).

However, in a recent critique, Pain et al. (2011:9) argue that such unidirectional conceptions of effect in academia "assume that the results and outputs of research are the only, or at least primary, means by which research has impacts on wider society. In this model, 'research' and 'impact' are separated in time, and researchers and users usually occupy separate spaces and activities." Some researchers have begun to question the language of the gap, suggesting that it implies a void needing to be filled or a divide to be bridged, and does not adequately recognize the capacities, value conflicts, and complex relations that already exist in the various spaces and places in which scientists and the public interact (van Kerkhoff and Lebel 2015; A. H. Toomey, A. T. Knight, and J. Barlow, unpublished manuscript).

Envisioning impact as something that happens not only at the end stages of research, but throughout the process, points to the need to explore the multiple spaces where the practice of "impacting" takes place (Whittle et al. 2011, Pain 2014). Shapin (1990:990), a science historian, once noted that a remarkable feature of the way we think about present-day science is that we think we know with certainty "where science ends and where other forms of culture begin." Whereas scientific knowledge is often thought of as something specialized, technical, and produced apart from the rest of society (in laboratories and universities), literature from the social sciences presents a more diverse picture of how and where knowledge is produced (Latour and Woolgar 1979, Latour 1987, 1999, Livingstone 1995, 2003, Lorimer 2008).

${ }^{1}$ Lancaster Environment Centre, Lancaster University, ${ }^{2}$ Center for Biodiversity and Conservation, American Museum of Natural History 
In the field, people are needed to carry equipment, cut trails, guide, and cook (Kohler 2002). Wherever it is done, scientific research requires certain kinds of permissions attained at different levels of society, from official research visas to oral acceptance from a village chief. And, even if it is not always recognized as doing so, Western science incorporates (or actively ignores) many different kinds of knowledge (Harding 1991, 2006, Ellis and Waterton 2004, Lowe 2004). Thus, it is vital to take a closer look at these spaces to understand how what happens within them can have a significant effect on how the research itself is perceived.

In this paper, I use evidence from Bolivia based on interviews and workshops with park guards, indigenous communities, and scientists to explore the following questions. What kinds of spaces exist when scientists carry out research? What types of encounters and misencounters occur between people in these spaces? What are the implications for scientists looking to bridge the knowingdoing gap? This paper is explicitly written for a multidisciplinary audience, but especially for natural scientists who may be less familiar with how science and society relations have been discussed by social scientists over the last several decades. I will introduce the reader to theoretical concepts of contact and encounter, and support these theories with detailed examples of how scientists and local people interact based on 15 months of fieldwork carried out in the Madidi region of Bolivian Amazonia. This is an important contribution because there is increasing recognition among conservation scientists of the need to incorporate different social theoretical frameworks and methodologies into the environmental sciences, but unfamiliarity with different epistemologies means that these perspectives are often ignored (Moon and Blackman 2014, Nielsen and D'haen 2014). To look more in depth at who and what exists within the gap, I now turn to theories of contact and encounter that have examined relations between different groups and cultures in diverse settings.

\section{Theories of contact and encounter}

The term "contact zone" is attributed to scholarship by Pratt (1992:8), who first used it to describe "the space of imperial encounters" in which peoples on different sides of the colonial equation, such as naturalist explorers and indigenous groups in South America, "come into contact with each other and establish ongoing relations, usually involving conditions of coercion, radical inequality, and intractable conflict." Other scholars have described contact zones as spaces of "heterogeneous and unequal encounters" in which different peoples, values, worldviews, and knowledges can rub up against one another and ultimately "lead to new arrangements of culture and power" (Tsing 2005:5; Torre 2010). Highlighted in this literature is an understanding that such spaces are never neutral but laden with power, and as such, what happens within them cannot always be anticipated and/or controlled (Lefebvre 1991, Clifford 1997, Cornwall 2004, Gaventa 2006). The resulting influences are far from one-sided. As Haraway (2008:219) writes, "contact zones change the subject all the subjects - in surprising ways." So, while such encounters may be "fraught with contestation and conflict," they also contain within them the potential for "connection, empathy and contract" (Sundburg 2006:239; see also Joseph et al. 1998).

These images and metaphors are extremely important for thinking more in depth about the different spaces within the gap between research and implementation and for seeing such spaces of encounter as the stage upon which new things might be possible. In Spanish, the word encounter can be translated to the verb encontrar, which means not only to meet, but also to find. Thus, an encuentro is not a simple coming together, but invokes possibilities of new discoveries, just as a desencuentro (misencounter) denotes not simply misunderstanding and miscommunication, but also a lost opportunity in seeing with new eyes. Making use of these ideas in the conservation sciences can allow us to think more deeply about how the micropractices of scientific research and the interpersonal relations among those involved in the process can affect existing ways of knowing. This brings to mind notions of reciprocal and relational impact as twoway, rather than linear (Pain et al. 2011). In this way, the complexity of encounter is a useful lens through which to examine how inequalities and misunderstandings between different groups can be reproduced through the practice of scientific research, as well as to understand how the spaces within the gap harbor the possibility for positive change.

\section{METHODOLOGY}

The empirical evidence on which the results are based were collected in the Madidi region of Bolivia over the course of 15 months (between 2012 and 2014) with three stakeholder groups: scientific researchers working in the region (mainly from the biodiversity and conservation sciences), indigenous community members and leaders, and protected area staff (from Madidi and Pilón Lajas). I came to the findings described here, not through having developed an analytical framework of encounter a priori to entering the field, but rather more directly, by finding myself implicated in many of the spaces of encounter and misencounter described in Results. Whereas I arrived in Bolivia in 2012 seeking practical ways to bridge the gap through participatory research, when I ultimately left in 2015, my view of knowledge had shifted, as in Roux et al.'s (2006) description, from seeing it as a thing to be transferred to an intimate and complex process of relating to others. During my time in the field, I became increasingly aware of my own role, as a white foreign researcher, in the continuation of a long and contested legacy of scientific research in Bolivia. Reflecting on my experiences greatly shaped the way that I have conducted, analyzed, and written about this research.

\section{Study site}

The Madidi region of Bolivia is located in the northwest department of La Paz and incorporates Madidi National Park and Natural Area of Integrated Management (NP/NAIM) and the surrounding area. At the 2012 IUCN conference in Korea, Madidi NP/NAIM was announced to be "likely the most biodiverse place on the planet," making it a priority area for scientific research, where two-thirds of its biodiversity is yet to be discovered (WCS 2012). Madidi covers approximately $19,000 \mathrm{~km}^{2}$ across the tropical Andes and is bordered by three additional protected areas: the Pilón Lajas Biosphere Reserve and Communal Lands and the Apolobamba Natural Area of Integrated Management in Bolivia, and the Bahuaja-Sonene National Park in Peru (SERNAP 2006). The communities located within and adjacent to Madidi NP/NAIM comprise lowland Amazonian indigenous groups (Takana, Leco, Tsimane', Mosetén), highland Quechua-speaking peasant farmers, and farming communities that self-identify as intercultural, which are 
often of mixed Aymara and lowland indigenous heritage. Four indigenous territories overlap the protected area (San Jose de Uchupiamonas, Takana I, Lecos de Apolo, and Lecos de Larecaja), and two others border Madidi (Tsimane'-Mosetén and Takana II). In total, there are approximately 25,000 people living in Madidi's area of influence (SERNAP 2006).

\section{Methods}

Quantitative assessment of previous research in Madidi A systematic analysis of research carried out in Madidi NP/ NAIM between 2004 and 2013 was done through an exhaustive review of documentation physically located in the Madidi park offices, recording all permit applications and other references related to scientific research in an Excel database in November 2013. A total of 88 research projects were identified, for which I attempted to contact the principal investigator(s) listed on each project to verify the information obtained and to ask additional questions about the level of local involvement in the project, potential implications for management, and extent to which the research results were disseminated and published. Complete information was gathered for 40 of the projects, and the quantitative data presented are based on this subsample of projects (see Appendix 1 for additional information).

\section{Qualitative methods}

Qualitative methods included (1) semi-structured and unstructured interviews $(N=137)$, (2) workshops and focus groups $(N=12)$, and (3) participant observation with researchers, local people (leaders and community members), and park guards and administrators. Interviews and workshops were held to understand different perceptions about the practice of scientific research and natural resources management, including interviewees' experiences in the past and suggestions for the future. Questions and the focus of all interviews and workshops varied according to the situation and participants (see Appendices 2 and 3 for more details). As noted by many scholars, complex power relations are embedded in participatory research processes (Cooke and Kothari 2001, Mohan 2001, Fairhead and Leach 2003, Pain 2004, Blaser 2009); in the research described, here I struggled with various issues, especially in the indigenous communities, including gender imbalances (Guijt and Shah 1998), workshop fatigue (Mistry et al. 2009), and the pace and control of the research process being mainly in my hands as the foreign researcher (Pain and Francis 2003). Prior informed consent was obtained for methods, and in some cases, the interviewee requested his or her name to be specified. To respect this wish, I have cited the author(s) of quotes or findings by listing their first initials and last names in the text when possible, with full names and additional information in Appendix 4. Data analysis was assisted with the coding software Atlas.ti. version 7.1.8.

\section{Defining "scientist" and "research"}

My focus here is on the practice of scientific research in the context of biological conservation, and the examples given in Results refer to a multitude of research projects studying aspects of flora, fauna, conservation, and natural resources use. However, in this discussion, I use the terms "scientist" and "researcher" somewhat interchangeably, and the term "research" as a collective activity representing many different disciplinary forms of gathering knowledge, to make generalizations about the ways in which such activities are perceived by those who are not aware of the often subtle variations between different types of scientific practice. Smith (1999:71) writes, "criticism of individual researchers and their projects is deflected by the argument that those researchers are different in some really significant 'scientific' way from others. How indigenous communities are supposed to work this out is a mystery." This idea will be further explored.

\section{RESULTS: SPACES OF LOCAL INVOLVEMENT IN RESEARCH}

Field-based scientific research is a largely social activity incorporating the participation and input of many nonscientists. In the Madidi region of Bolivia, in the quantitative analysis of previous research carried out, $78 \%$ of researchers $(N=40)$ stated that they had involved local people in the research process in some way, and $90 \%$ of studies were carried out, at least part of the time, within close proximity to local communities. In these studies, $58 \%$ used local people as paid labor (guides, porters, or drivers), and $35 \%$ actively incorporated different forms of local knowledge into the research through interviews, surveys, or workshops. A smaller number of researchers $(10 \%)$ additionally involved people in the collection of data by training them in various biological research methods such as line transects for the surveying of large mammals or studying breeding patterns of endangered bird species. The implications of this proximity and involvement of local people will be explored in further detail in the context of seven types of "spaces" that occur during the process of conducting scientific research. The selection of the spaces is not intended to be exclusive, as there are other types of spaces that could be written about in depth (such as dissemination), but these seven spaces emerged through the analysis of the qualitative data as being particularly important because the have received little or no attention in existing literature on the gap.

\section{Spaces of arriving and getting permission}

Scientists may not typically consider themselves to be among the powerful; indeed, they frequently bemoan their relative lack of power in affecting policy and making desired change (Terborgh 2004). However, just because scientists and researchers are not always aware of the power that they hold does not mean the nonscientists they encounter during their fieldwork are also insensitive to power dynamics (Barbour and Schlesinger 2012). As one indigenous leader, who had a great deal of experience working with researchers, said, "Scientists often act as if they were in a virgin forest in the middle of nowhere, doing their work as if there weren't people living there," (S1). In some interviews with scientists, especially informal situations where the recorder was turned off, comments sometimes revealed a kind of frustration or disdain toward local people. Complaints or requests were occasionally perceived as a simple hindrance to be dealt with quickly and efficiently, perhaps by buying a sack of a farmer's potatoes to have access to their land, as, "After all, all they really want is the money," (S2). Such attitudes reveal a great lack of awareness about one's own relative position of power (as an outsider who can buy his or her way onto the land) and a failure to recognize the historical and cultural reasons for mistrust and concern on the part of the locals.

In Madidi, there exists a unique vocabulary around the practice of scientific research that is used by local people to explain certain 
observations and sentiments they have with regard to the activity and those who carry it out. One Spanish word commonly heard is susceptibilidad, which is a more complex concept than the dictionary translation of "susceptibility" seems to allow. This is exemplified by the quotation from Cesar Bascope, a park guard native to the region:

\begin{abstract}
People in these communities have a lot of susceptibilidad; when they see a tourist or an outsider they feel taken off-guard. They aren't used to having strangers around - they are very guarded in the communities. If an outsider arrives, in their heads they are always thinking, "Who is this person, why are they here, what are they going to do, do they have money?" They ask themselves these questions, and that's why it's important (for researchers) to inform them from the beginning about what they are going to be doing (S3).
\end{abstract}

What is expressed with this word are feelings of sensitivity, vulnerability, and uncertainty, where one must be misquino or guarded with one's knowledge and information, because to do otherwise is to take a risk that will likely not be rewarded, but rather exploited, by someone more powerful than oneself. The Madidi region of Bolivia, like much of Amazonia, has a long history of colonialism and nationalization of natural resource extraction and has been home to many resource booms over the 20th century (i.e., rubber, quinine, and timber). The local inhabitants have learned that if outsiders come looking for natural resources, some inhabitants will benefit and others will lose out (Lehm et al. 2002, Silva 2002). As Valentine (2008:333) writes, "encounters never take place in a space free from history, material conditions, and power" (see also Sharpe 1998, Cepek 2011). With regard to the practice of scientific research, this kind of losing out has come in the form of experiences with biopiracy and the patenting of traditional knowledge (Laird and Lisinge 2002). Celín Quenevo of the Takana indigenous people, speaks about the history of indigenous organizations in the region developing research agreements with scientific organizations:

\section{We began to realize that some of our natural resources were being patented, and that the traditional knowledge of our communities was being taken by researchers. They were patenting the process of elaboration, of how the plant is used by the people for healing and health. So this realization generated a national debate among the indigenous organizations to be able to develop a way to control research in the territories, and to ensure that those who enter do so with the permission of the leadership councils, based on what is being researched and for what purpose (S4).}

This combined history of natural resources exploitation and scientific exploration has led to much confusion over the activity of research. A common complaint among researchers newly arriving to the field to get permission were the demands, often monetary, that local people would make of them. However, researchers are not always aware of the long histories that local people have had with previous researchers who made promises that they neglected to keep, particularly with regard to the basic dissemination of research results (Shanley and Laird 2002, Boreux et al. 2009). This feeling of suceptibilidad is often linked in discussions about research to the use of another word, recelo, meaning mistrust or suspicion:

There is a lot of resistance among the local communities when researchers come. Because generally, researchers explain things very quickly and then they leave without giving back the results. And so [the local people] don't know if there were any benefits accrued in the long term as a result of the research, or if it was only for the researcher who did the work to obtain funds for his organization or for himself. Because of this, the people have a lot of recelo when it comes to research (E. Romay, S5).

Another area of difficultly lies with who grants permission. Because Madidi is a highly culturally as well as biologically diverse region, the practice of scientific research requires not only methodological skills in one's given academic field, but the ability to negotiate across social and cultural divides, i.e., with protected area staff (at both the national level and the regional park level), with authorities in indigenous and peasant farming communities, and also occasionally with municipal government officials. Although many indigenous groups have protocols and agreements to negotiate relations with researchers, such as those described by Celín above, such decisions are often made by the leadership councils that are located in more urban centers at a distance from the rural communities where the actual research will take place. Leadership councils often have different reasons for accepting researchers in their territories, which can include, among other considerations, potential alliances and projects with the scientific institutions, the promotion of the needs and concerns of the group on a national or global scale, and personal benefits accruing to the leaders themselves. These reasons are not always shared by the members of the communities where the fieldwork will take place, but, because of the hierarchical nature of such leadership structures, the option for rejecting researchers in the communities after they have official approval from the leaders is not always deemed possible (S5, S9). This situation can potentially erode local autonomy and pave the way for misencounters in the field, as arriving researchers may be surprised to discover that official approval as authorized by an indigenous leadership council to conduct their research does not ensure local support (S6).

\section{Spaces in the field: local labor}

The previous section outlines a kind of "elite capture," which has been written about in development literature to refer to a process by which projects or initiatives promoted by outside groups such as development or conservation organizations "invariably privilege certain actors while marginalizing others" (Sundberg 2006:259; see also Chambers 1983, Platteau 2004, Nielsen and Lund 2012). Because such negotiations often take a great deal of time and flexibility, many researchers take shortcuts when they can, which sometimes means limiting their interactions with local people to those in positions of power over those who have less of a voice in a given community. For example, there are certain characteristics that researchers look for in the local guides that they hire: their knowledge of the forest, their ability to negotiate difficult social and cultural encounters (either within their own community or with other communities), as well as their general 
level of understanding of the research to be carried out. Oftentimes, researchers allow the community itself to choose who will guide the expedition. All of these factors mean that, more likely than not, those interacting with the researchers are those in higher positions of power in the community, usually men, from the wealthier families. Because of the cumulative educational nature of participating in scientific research (even as a guide or a porter), those chosen initially are likely to be chosen again. However, the power relations in this form of labor are clear: the scientist is boss, and the local guide is subordinate. Raffles (2002:177) writes about this in his book, In Amazonia, in which he describes how one guide became so skilled (and willful about the way things should be done) that scientists no longer wished to hire him:

\section{From the first day the irony begins to unfold. The more successfully (the guide) teaches, the faster the visiting scientist learns to be independent. Within a couple of years, the project is established, the team is trained, the area mapped, the replicates in place, and everything has settled into a secure routine. Once indispensable, his skills are no longer needed. And his price, which has risen steadily over the years, is too high.}

Where the benefits of scientific research are distributed unequally in a community, it can also be expected that perceptions and levels of understanding of scientific practice will be varied. Workshops, meetings, and interviews with members of two highly researched indigenous communities revealed a wide spectrum of different (mis)understandings about scientific research and researchers themselves. Higher power community members (men, leaders, people with outside links) tended to speak about research in ways that reflected Western perceptions, but they were also more likely to voice concerns about the lack of results left behind. In contrast, lower power community members (women, elders, those with less education) had more varied understandings of research that would be less compatible with scientific definitions. For example, in one workshop, the women present said that they understood research to mean "investigate" in the same sense an authority might investigate a robbery (the Spanish word for research is investigar), but that otherwise they had never heard of the term before (S7). Women were also more likely to use terms such as "volunteers" or "tourists" when describing those who had come to do research on their lands. Smith (1999:85) writes of the challenge of trying to glean interpretations of research from colonial-era oral stories, because at the time the indigenous people involved did not know that they were being researched: "Research could not be disconnected from other European activities. 'Researchers' were also missionaries, amateur botanists, surveyors, officials, traders - any European, in fact, who was able to write or draw pictures."

This challenge is still current today: one major limitation of this research is that many people found it difficult to discuss a concept that they did not understand. During conversations, interviews, and meetings with people from local communities, it became clear that many people had difficulty in differentiating what research is, and who researchers are. For example, one young man told me repeatedly through the duration of my fieldwork in Madidi about how his indigenous community had a problem with researchers and took me to the community to discuss the issue with his neighbors. However, it was almost two years after we first met that he asked me to explain to him in clear terms what research actually meant, and what it was for (H. Nay, S8).

These differences in understanding may then generate new hierarchies or divisions within a community because new forms of knowledge challenge lower status, vernacular ways of knowing as being backward or unimportant. These issues have been discussed in the literature about decolonizing research and revaluing traditional ways of knowing and doing, and will be discussed further in the next section (see also Smith 1999, Chilisa 2012, Walsh 2012).

\section{Spaces of knowledge exchange}

Even as it is becoming politically correct in scientific communities, particularly in Latin America, to acknowledge the value of local and traditional knowledge systems, in practice, many scientists regard their knowledge as superior to that held by those who live or work in a given region, especially if those people are illiterate (Verran 2002, Chilisa 2012, Cozzuol et al. 2014). Local people are not blind to these superior attitudes, and many people shared with me misencounters that they had had with scientists in which their local knowledge was laughed at or disregarded. Taxonomy is one frequent issue of contention; during fieldwork encounters, it is common for different forms of ethnotaxonomy to come into conflict with the Linnaean system (Berkes 1999, Cozzuol et al. 2014). During interviews, people often mentioned flora and fauna that were not yet "in the lists," which they often framed as "things that scientists do not believe in." For example, one young man who had worked as a guide for a foreign herpetologist recalled how the scientist would laugh at knowledge held by community members of snake classifications and behavior, such as a local differentiation between two types of bushmaster (Lachesis spp.), one that lives on the ground and is aggressive, and the other that lives in the trees and is harmless (S10).

Sometimes, local people will directly refuse to work with scientists who act disrespectfully toward their beliefs and knowledge, as was made clear by a Takana woman who told me that when an agronomist from the city dismissed the ideas of the local farmers, the community asked him to leave (L. Supa, S11). On the other hand, the relatively high status level of many scientists is intimidating for many local people, which, in Bolivia, is emphasized by the common practice of using academic titles when addressing someone, such as ingeniero (engineer) or licenciado (literally, "licensed" with a bachelor's degree). In such cases, rather than explicitly rejecting their presence, local people expressed their resistance to the researchers or their work in more passive ways, such as claiming ignorance in response to questions, or deliberately giving misleading information, reflecting a kind of everyday resistance to power relations (E. Romay, S5, also see Scott 1985, 1990). For example, in one community, several inhabitants told me about a "useless" study in which a scientist was measuring the "wrong part" of a palm tree to record its growth. They admitted to laughing about his mistake behind his back, but said that no one directly questioned him during the length of the study (S9).

However, in other interviews, people talked about specific things they had learned as a result of being involved in the research in some way, whether such learning gains were attributed to new techniques for obtaining knowledge or the new knowledge itself. 
One man who served as a guide for botanists explained that he enjoyed the work because he learned about medicinal plants in the region, "Some of which we didn't know about either," and described the experience as one of conocer, or coming to know (M. Alvarez, S12). Another guide said that, on an expedition, he was amazed to learn that there exist $>20$ species of laurel (Lauraceae) in the forest (H. Pariamo, S13). Related to the process of conocer is that of knowledge exchange, where both parties can learn from one another. Interviews revealed the importance of this exchange during fieldwork, and often, locals who had served as guides followed up on comments about their own learning gains with affirmations that, "We taught them as well," reflecting how scientists and locals can have different knowledge about things of mutual interest (R. Cuevas, S14). One scientist connected the recognition of local peoples' own knowledge as a way of expressing respect:

\section{To let them know that we're not just going to teach them what we know, but to express that we know we will learn a great deal from them as well. We need to be clear on how much we need them - as guides, for knowledge-to make them feel that they are very important for the study, that it cannot be done without them. I believe that respect needs to come first and be a constant factor when working with local people (S15).}

\section{Spaces of relevance}

Key in this discussion is the question of for whom such scientific information is relevant. Interviews revealed the common perception that most research is simply for the tesista (literally, thesis-maker) or researcher and is of no local relevance (S9). Even for research that actively engages with participatory methodologies, local people may have very different reasons for participating that do not reflect shared perceptions of the ultimate purpose of the research (Blaser 2009, Cepek 2011, Nielsen and Lund 2012). This brings up a discussion of the complexities inherent in research processes that aim for knowledge integration, because of power imbalances between Western and indigenous systems (Agrawal 1995, 2002, Nadasdy 2003, Heckler 2007, Bohensky and Maru 2011). McGregor (2004) argues that Aboriginal people view indigenous knowledge as something that should not be studied because it can only be expressed by doing.

Similarly, discussions with local people in Bolivia revealed that scientific or "new" knowledge could be viewed as being complementary to traditional knowledge to the extent that it could be directly put into practice (see also Centellas 2010). In the Madidi region, for example, Western medicine is combined not only with the use of local plants and animals, but with the help of curanderos, who attend to the spiritual side of things such as removing bad spirits or shadows from the patient (S16). Lowland indigenous peoples such as the Takanas maintain certain beliefs about the origin and control of animals in the forest by spirits called Edutzis, who have the power to determine the success of hunts and to punish those who take more than they need (Lara 2003). But increasingly, territorial leaders also refer to concepts of extinction and conservation as being important for guiding decisions about land use and hunting, which points to the nonstatic nature of knowledge (S16, S17). Additional interviews revealed that local people appreciated Western ecological knowledge to the extent that research findings were relevant for ecotourism, such as where the highest density of jaguars could be found or regarding the discovery of new species (S18). However, the area of most importance, especially for indigenous leaders, was concerned with the extent to which scientific research could be seen as a tool to support selfdetermination and endogenous development strategies on communal lands. For example, one indigenous leader stated, "If we don't have the information, how can we protect ourselves? We need to think about how to come up with counterproposals to the government's plans for megaprojects in the region," (G. Mamani, S19).

This points to Davies' (1994:20) reflection, “It is less the case that knowledge is power, than that the use of that knowledge is an expression of power." Developing relational and ethical modes of scientific practice is not something that is limited to encounters in the field, but is also concerned with how the resulting information will be wielded in academic, professional, and policy circles.

\section{Spaces of friendship}

Another space of encounter between researchers and local people is that of friendship and relationships of care. Interviews with all of the groups involved brought up the personal effects that such human interactions had on them; comments invoked feelings such as nostalgia, friendship, disappointment, guilt, and responsibility. Although specific experiences were highly varied, one commonality in many of the interviews was the individualizing of certain groups. Communities became distinct from one another: scientists were not just los tecnicos, but referred to by name; the knowledge and talents of certain guides were remarked upon and differentiated. On one trip to a community with a biologist who had worked there 10 years earlier, she broke into tears at seeing familiar faces; that same biologist was remembered fondly by many local people in interviews. She told me that her ideas about conservation and her role as scientist had changed as a result of spending years working with indigenous hunters and fishers as part of a participatory research project, "You learn to care about the people in communities when you get to know them, when you see how they live," (M. Copa, S20).

The value of such "getting to know" takes on additional importance in looking at how relationships between different groups can develop and strengthen through daily expressions of respect and care. For example, during the period of this research there were particularly strong relationships between the Madidi park guards and the scientific support staff (two young women from $\mathrm{La} \mathrm{Paz}$ ) hired to assist in the implementation of a rangerbased monitoring project. One of the park guards, Juan, made the following comments when asked about the project:

I think the monitoring is really important. [The
biologists] work really hard to help us, sometimes staying
up late into the night to answer all of our questions.
Sometimes they come with us on our patrols, even in
places where it's not easy. There are dangers in the forest
-insects, snakes - but even though they're from the city,
they don't get tired, as if they were from the country. They
patrol with us (J. Ortiz, S21).

However, it is important to be aware of the power dynamics inherent in these relationships, something that previous studies 
of spaces of friendship have explored (Han 2010, de Leeuw et al. 2012, Jones and Ficklin 2012). One aspect refers to the asymmetrical nature of such friendships and personal relationships (Torre 2010, Askins and Pain 2011, Askins 2014). For example, in Bolivia, an integral part of society also relates to the practice of naming padrinos (godparents) for important events in a person's life (e.g., baptism, communion, certain birthdays, marriage) and a community's life (e.g., festival days, high school graduations, inaugurations), and it is very common for both foreign and national researchers to be asked to take on this role, which offers the potential for an outsider to be brought further inside the daily workings of a community or family. However, complex social relations and expectations are embedded in these relationships, and godparents are often selected because of the outside power and resources they are imagined to command (Mayer and Bolton 1977). This can lead to unmet expectations and feelings of confusion and hurt on both sides of the relationship if researcher-padrinos are not aware of what is expected of them. I experienced this personally, being asked (and accepting) on three separate occasions to serve as a godmother, but ultimately being unable to meet the expectations of the families in two of the situations, and feeling mislead in turn.

However, interpersonal connections are a highly valued aspect of ethical research relationships (Routledge 1996, Torre et al. 2008, Torre 2010). Spaces of friendship have the potential to open up further opportunities for deeper reflection and eventual change by shifting preexisting biases (Allport 1954). Askins (2008, 2014) refers to this as a "transformative politics of encounter." Indeed, scientists in Bolivia are beginning to become aware of this, as expressed in the following quotation:

We see that things are not equal. We go to these places because they've paid us to do so, because we are consultants, because we have to research a certain thing... And sometimes we treat the local people as if they were just employees - that they have to do everything we say. But that is where I think we can change (S15).

So rather than a space of equality in itself, relations of friendship and care could be seen as representing spaces of hope, based on the idea that it is in such interpersonal (if complex) interactions where ethical relationships can find their feet (Barnett and Land 2007).

\section{Spaces of analysis and acknowledgement}

Much of the frustration and resentment expressed in interviews with local people is related to feelings about who gets credit in the process of research. Official recognition in written form for one's contribution to the research process was something brought up by many local people. At the start of one interview, a man who had served as a guide for many scientists handed me a scientific journal written in English in which his name was listed in the acknowledgements of a botanical paper (H. Pariamo, S13). In another situation, a different man flipped excitedly through a guide of plants that had been produced by scientists he had worked with and was clearly disappointed when neither his name nor his community was mentioned in the text (M. Alvarez, S12). One young man in the Takana-Quechua community of San José de Uchupiamonas expressed anger at the lack of recognition extended to his parents, especially his father, who was often approached by researchers because of his vast amount of knowledge about local flora and fauna. He lamented that his father, who had just died at the time of our conversation, was leaving behind no legacy despite having participated in so much research, and he added that this was a common experience among many people in his community (S10). Such experiences reflect writings by indigenous scholars regarding the perspective of research as theft (Smith 1999, Rigney 2001, Walter 2005, Robbins 2006, Louis 2007). Another man who had served as a guide for many researchers said that while some scientists always remember to send photographs, letters of acknowledgement, and thanks with all of the names of those involved, others leave nothing behind: "They just do it for the fame of working in Madidi," (S1). This points to different understandings of authorship, especially in terms of local knowledge, an area of complexity when discussing the "discovery" of new species, or the documenting of traditional knowledge of plants for their medicinal uses. Clemente Caimani of the Tsimane'-Mosetén indigenous people, put it as follows:

For a researcher or for the writer of a book about traditional knowledge, the author is the indigenous person - the community, the interviewed person. The interviewer is only the compiler of the information that he takes away, perhaps for his research, for his own knowledge, to teach or share with others, or for his degree. But the principal author is the indigenous person or community, because he's taking the information from them (S22).

In another interview, a park guard said that he no longer shares information with scientists because of past experiences in which scientists did not formally recognize the role that park guards and local people played in providing them with information critical to new discoveries.
It's because of this that now many park guards who know about species that haven't yet been documented for science don't want to say anything about it. Because they know it will be said that "the biologist so-and-so discovered the species," not the park guard (R. Chivapuri, S23).

However, I found that both scientists and local people are beginning to change their roles in this regard. For example, indigenous leaders with more experience working with scientists have begun to request that they be listed as coauthors on scientific papers, and I found evidence of scientists of many disciplines putting this into practice. Celín Quenevo recounted a process of demanding acknowledgement through coauthorship and data analysis:

We published jointly with the scientific organization and were coauthors because it was important that they take into account the participation of the indigenous organization, the communities, mention the specific medicinal plants that had been collected, and how they analyzed them in the laboratory with regard to each plant that could be useful medicinally, whether or not it was interesting to the pharmaceutical company or not. We went to the laboratory also, because we'd seen how our Tsimane' brothers had been taken advantage of previously, so we knew we needed to follow up on what 


\section{they did with our leaves, how they processed them and} separated the molecules (S4).

Likewise, as indigenous leaders have begun to take control over certain research processes on their lands, scientists are responding accordingly and making adaptations to their own ways of working. This is a very tricky area to negotiate because it is not simply a question of making research more participatory or giving token nods to indigenous knowledge through the post hoc adding of names to papers. Rather, meaningful negotiations regarding who gets credit require a deeper attention to the complex power relations continually at play within these spaces of analysis and acknowledgement (Spivak 1988, Cooke and Kothari 2001, Jazeel and McFarlane 2010, Barbour and Schlesinger 2012). Scientific publication (at least in theory) requests that all authors have read, understand, and approve of the content in a given manuscript, which requires that there must be spaces made for input on how the research was analyzed or written about prior to publication. This is very difficult to achieve across language, education, and cultural boundaries, which is why, for example, I am the single author on this paper, despite having drawn its content from interviews and interactions with $>100$ people, all of whom would surely have presented this material in a different way.

\section{Spaces within}

Encounters and misencounters between different groups around the practice of scientific research can be the basis for selfreflection, where people begin to question their own ways of seeing the world and be more open to new ideas and different kinds of people (Barnett and Land 2007). In Madidi, interactions between local people and scientists changed not only the way they thought about one another, but additionally, how they viewed their own roles and ways of being. Among conservation scientists, there is also growing awareness of this issue. One Bolivian biologist, the head of a large conservation science organization, told me that in recent years, she has come to appreciate the importance of finding ways to support different forms of knowledge and decision making through their work in the region:

\section{If you had asked me 15 years ago, 10 years ago, even 5 years ago, I wouldn't have seen things in this way. But as you work with these issues, you begin to perceive how some information is valued and how other ways of thinking are devalued, and you realize how fundamental these are to how people manage their own territories $(\mathrm{L}$. Painter, S24).}

Some local people told me of how they had come to value their own knowledge in relation to that of the scientists and, once becoming more familiar with the terminology of research and science, were able to articulate their own role as researchers. In interviews and workshops, local people clearly perceived their more practical knowledge to be equal in value to the scientists' knowledge. As one man said, "The farmers are the most constant researchers because they are always in direct contact with the earth, with their crops," (S25). Another local hunter commented to me that he was also a licenciado, which is a term used in Bolivia to refer to those with university degrees, "You are the biologist of theory, but I am the biologist of the forest," (E. Cavinas, S26).

Many scientists in Bolivia are beginning to change how they see their roles and to question their own positions of authority. This was apparent not only in how they spoke about their responsibilities to local communities, but how they interacted with people while in the field. This is reflected in a quotation from a botanist from La Paz, who spent one year doing ethnobotanical research in an indigenous community in Madidi:

I think that we have to learn to be much more open. We can't arrive somewhere and just say, "We are the scientists." We have to start to think like they do. We also have to try to get them to ask questions and put themselves in our place (S15).

\section{DISCUSSION AND CONCLUSION}

This paper contributes to current debates in the conservation sciences on the knowing-doing gap by shifting the focus away from the dissemination stage and toward forms of scientific impact that are often not anticipated or intended because of the complex relations that occur in the field. The different types of spaces presented demonstrate how the multiple histories, knowledges, experiences, and worldviews that play out during the process of knowledge production can have great implications for how scientific knowledge is perceived and (mis)understood, especially in non-Western settings. Each of the spaces selected for analysis could be explored in further detail; I explored the scope and breadth of issues around the practice of scientific research, rather than focusing on any one particular case study or specific concern. In addition, the spaces mentioned here were not intended to represent an exhastive list, and further research could shed light on other spaces of encounter and misencounter that occur throughout the practice of research. Notwithstanding these limitations, this research offers three key insights for conservation scientists concerned with the impact of their research.

First, we need to think more deeply about what impact is and how it is achieved. Rather than the linear models of impact that evidence-based conservation papers tend to advocate, encounter brings to mind an understanding of impact that is two-way, based on the notion of relational accountability (Louis 2007). This suggests that researchers need to develop new capacities and skills to understand what is happening in the spaces within the gap and develop strategies for dealing with the subtle, sometimes unconscious manifestations of power that emerge from encounter (Barnes 1996, Cepek 2011, Nielsen and Lund 2012). Although there are no blanket solutions for how to deal with the many issues raised here, which depend on many factors and are perhaps best resolved through deep processes of negotiation and reflection, researchers can take steps to ensure that they are as prepared as possible. First, they can understand that impact begins to occur before researchers even enter the field; places have their own unique histories, and researchers would be well advised to try to learn as much as possible about the history of scientific research and conservation in a given place before bringing in a new project. Reading about the social, cultural, and political contexts of a region is one way to achieve this; another way is to conduct a thorough social reconnaissance by spending time with and talking to local people and other stakeholders about their past experiences and current concerns. Researchers and scientific teams can do additional preparation by attempting to anticipate issues that may arise and requests that may be made of them prior to beginning the research. They can undergo training on intercultural communication and seek advice from other 
disciplines on how to be more flexible and proactive in their negotiations with local people. One relatively straightforward solution is to give social science (and social scientists) a more central role in conservation research in general.

However, for any of the above to happen, researchers need to be open to change, and one extremely useful tool in this regard is that of constructive critique. Because critique is so often associated with painful and negative feelings and experiences, its potential for driving change is often ignored or avoided. However, when it is viewed as a lens of curiosity through which to see old situations in a new light, its true power can be grasped. Critique can help us to understand better the roots of the problems that we seek to overcome, as well as to come to terms with our complicity in such situations. This is not about blaming, but rather about encouraging acknowledgement of existing problems and giving examples of how different groups are beginning to question and change their own practices. After all, researchers who do not recognize mistakes and misunderstandings in the field do themselves (as well as future researchers) a disservice because access to research sites and the quality of the data may be compromised as a consequence of refusing to deal in a constructive way with such issues.

However, critique is not very useful if there is no belief that things can be changed. As Chatterton (2008:426) writes, "Let's save our pessimism for better times." In this spirit, I point to the spaces between research and practice as laden with the possibility of mutual transformation by demonstrating how encounter can cause shifts in perception and create new opportunities, even in the context of unequal relations (Torre 2010). Concepts such as public engagement and community participation do not always result in shared understanding or equality, but they offer the potential for new and unexpected things to happen, especially if those engaging in these spaces are open to such possibilities (Kesby 2007, Askins and Pain 2011). This raises a kind of critical hope for the potential of environmental research to serve as a mode of inquiry that is self-questioning, which "begins with an individual reflecting on his or her own values and making a decision to act towards positively changing their own behaviour, and/or facilitating others to do the same" (Knight 2013:389).

As a guiding force for my own practice, critical hope has meant acknowledging that I am implicated in, and thus have responsibility toward, the areas I have sought to explore and critique. Through the process of conducting the research described above and becoming more aware of the complexity inherent in encounter, I am slowly coming to understand what I need to change about my own practice to embrace the opportunity and potential in these spaces for the future. Finally, by seeking to communicate across disciplines through my writing, I aspire to disrupt current framings of impact in the conservation sciences, as well as encourage other researchers to reflect on their own roles in these processes. In this sense, open-access, multidisciplinary journals such as Ecology and Society can represent a further space of encounter for researchers of different backgrounds to learn from one another, to grow, and to change.

Responses to this article can be read online at: http://www.ecologyandsociety.org/issues/responses. php/8409

\section{Acknowledgments:}

This study was partially funded by Lancaster University and received additional financial support from the Rufford Foundation and the Royal Geographical Society. Special thanks to Bolivian project collaborators, including Maria Copa, Igor Patzi, and Armando Medinaceli, and additionally to Oscar Loayza, Huascar Morales, Hernan Nay, Zenon Limaco, and Andy Limaco for the generosity of their time and interest throughout this research. The manuscript benefited from thoughtful comments by Jos Barlow, Rebecca Ellis, Saskia Vermeylen, James Fraser, Hannah Griffiths, Emily Adams, and Erika Berenguer. Additional suggestions from the Biolunch research group at the Center for Biodiversity and Conservation at the American Museum of Natural History, as well as from two anonymous reviewers, were greatly appreciated. Finally, thank you to all of the people in the Madidi region who shared their thoughts and time with me over the last three years.

\section{LITERATURE CITED}

Agrawal, A. 1995. Dismantling the divide between indigenous and scientific knowledge. Development and Change 26(3):413-439. http://dx.doi.org/10.1111/j.1467-7660.1995.tb00560.x

Agrawal, A. 2002. Indigenous knowledge and the politics of classification. International Social Science Journal 54 (173):287-297. http://dx.doi.org/10.1111/1468-2451.00382

Allport, G. W. 1954. The nature of prejudice. Addison-Wesley, New York, New York, USA.

Arlettaz, R., M. Schaub, J. Fournier, T. S. Reichlin, A. Sierro, J. E. M. Watson, and V. Braunisch. 2010. From publications to public actions: when conservation biologists bridge the gap between research and implementation. BioScience 60 (10):835-842. http://dx.doi.org/10.1525/bio.2010.60.10.10

Askins, K. 2008. (Re)negotiations: towards a transformative geopolitics of fear and otherness. Pages 235-248 in R. Pain and S. J. Smith, editors. Fear: critical geopolitics and everyday life. Ashgate, Aldershot, UK.

Askins, K. 2014. Being together: everyday geographies and the quiet politics of belonging. ACME: an International E-journal for Critical Geographies 13(1):19-23. [online] URL: http://ojs.unbc. ca/index.php/acme/article/view/1175/985

Askins, K., and R. Pain. 2011. Contact zones: participation, materiality, and the messiness of interaction. Environment and Planning D 29(5):803-821. http://dx.doi.org/10.1068/d11109

Bäckstrand, K. 2003. Civic science for sustainability: reframing the role of experts, policy-makers and citizens in environmental governance. Global Environmental Politics 3(4):24-41. http://dx. doi.org/10.1162/152638003322757916

Barbour, W., and C. Schlesinger. 2012. Who's the boss? Postcolonialism, ecological research and conservation management on Australian Indigenous lands. Ecological Management and Restoration 13(1):36-41. http://dx.doi.org/10.1111/j.1442-8903.2011.00632. $\underline{\mathrm{X}}$

Barnes, T. J. 1996. Logics of dislocation: models, metaphors, and meanings of economic space. Guilford Press, New York, New York, USA. 
Barnett, C., and D. Land. 2007. Geographies of generosity: beyond the 'moral turn'. Geoforum 38(6):1065-1075. http://dx. doi.org/10.1016/j.geoforum.2007.02.006

Berkes, F. 1999. Sacred ecology: traditional ecological knowledge and resource management. Taylor and Francis, Philadelphia, Pennsylvania, USA.

Blaser, M. 2009. The threat of the Yrmo: the political ontology of a sustainable hunting program. American Anthropologist 111 (1):10-20. http://dx.doi.org/10.1111/j.1548-1433.2009.01073.x

Bohensky, E. L., and Y. Maru. 2011. Indigenous knowledge, science, and resilience: What have we learned from a decade of international literature on "integration"? Ecology and Society 16 (4):6. http://dx.doi.org/10.5751/es-04342-160406

Boreux, V., J. Born, and M. J. Lawes. 2009. Sharing ecological knowledge: opportunities and barriers to uptake. Biotropica 41 (5):532-534. http://dx.doi.org/10.1111/j.1744-7429.2009.00574.x

Centellas, K. M. 2010. The localism of Bolivian science: tradition, policy, and projects. Latin American Perspectives 37(3):160-175. http://dx.doi.org/10.1177/0094582X10366536

Cepek, M. L. 2011. Foucault in the forest: questioning environmentality in Amazonia. American Ethnologist 38 (3):501-515. http://dx.doi.org/10.1111/j.1548-1425.2011.01319.x

Chambers, R. 1983. Rural development: putting the last first. Pearson Education, New York, New York, USA.

Chatterton, P. 2008. Demand the possible: journeys in changing our world as a public activist-scholar. Antipode 40(3):421-427.

Chilisa, B. 2012. Indigenous research methodologies. Sage, Los Angeles, California, USA.

Clark, W. C., and N. M. Dickson. 2003. Sustainability science: the emerging research program. Proceedings of the National Academy of Sciences 100(14):8059-8061. http://dx.doi.org/10.1073/ pnas. 1231333100

Clifford, J. 1997. Routes: travel and translation in the late twentieth century. Harvard University Press, Cambridge, Massachusetts, USA.

Cooke, B., and U. Kothari, editors. 2001. Participation: the new tyranny? Zed Books, London, UK.

Cornwall, A. 2004. Spaces for transformation? Reflections on issues of power and difference in participation in development. Pages 75-91 in S. Hickey and G. Mohan, editors. Participation: from tyranny to transformation? Exploring new approaches to participation in development. Zed Books, London, UK.

Cozzuol, M. A., B. D. Thoisy, H. Fernandes-Ferreira, F. H. G. Rodrigues, and F. R. Santos. 2014. How much evidence is enough evidence for a new species? Journal of Mammalogy 95(4):899-905. http://dx.doi.org/10.1644/14-MAMM-A-182

Davies, S. 1994. Introduction: information, knowledge and power. IDS Bulletin 25(2):1-13. http://dx.doi.org/10.1111/j.1759-5436.1994. mp25002001.x

de Leeuw, S., E. S. Cameron, and M. L. Greenwood. 2012. Participatory and community-based research, Indigenous geographies, and the spaces of friendship: a critical engagement.
Canadian Geographer 56(2):180-194. http://dx.doi.org/10.1111/ j.1541-0064.2012.00434.x

Ellis, R., and C. Waterton. 2004. Environmental citizenship in the making: the participation of volunteer naturalists in UK biological recording and biodiversity policy. Science and Public Policy 31(2):95-105. http://dx.doi.org/10.3152/147154304781780055

Fairhead, J., and M. Leach. 2003. Science, society and power: environmental knowledge and policy in West Africa and the Caribbean. Cambridge University Press, Cambridge, UK.

Gaventa, J. 2006. Finding the spaces for change: a power analysis. IDS Bulletin 37(6):23-33. http://dx.doi.org/10.1111/j.1759-5436.2006. tb00320.x

Gossa, C., M. Fisher, and E. J. Milner-Gulland. 2015. The research-implementation gap: how practitioners and researchers from developing countries perceive the role of peer-reviewed literature in conservation science. Oryx 49(1):80-87. http://dx.doi. org/10.1017/s0030605313001634

Guijt, I., and M. K. Shah, editors. 1998. The myth of community: gender issues in participatory development. Intermediate Technology Publications, London, UK. http://dx.doi. org/10.3362/9781780440309

Han, J. H. J. 2010. Neither friends nor foes: thoughts on ethnographic distance. Geoforum 41(1):11-14. http://dx.doi. org/10.1016/j.geoforum.2009.09.007

Haraway, D. J. 2008. When species meet. University of Minnesota Press, Minneapolis, Minnesota, USA.

Harding, S. 1991. Whose science? Whose knowledge? Thinking from women's lives. Cornell University Press, Ithaca, New York, USA.

Harding, S. 2006. Science and social inequality: feminist and postcolonial issues. University of Illinois Press, Chicago, Illinois, USA.

Heckler, S. 2007. On knowing and not knowing: the many valuations of Piaroa local knowledge. Pages 91-107 in P. Sillitoe, editor. Local science vs. global science: approaches to indigenous knowledge in international development. Berghahn Books, New York, New York, USA.

Hulme, P. E. 2014. Bridging the knowing-doing gap: know-who, know-what, know-why, know-how and know-when. Journal of Applied Ecology 51(5):1131-1136. http://dx.doi.org/10.1111/136$\underline{5-2664.12321}$

Jazeel, T., and C. McFarlane. 2010. The limits of responsibility: a postcolonial politics of academic knowledge production. Transactions of the Institute of British Geographers 35(1):109-124. http://dx.doi.org/10.1111/j.1475-5661.2009.00367.x

Jones, B., and L. Ficklin. 2012. To walk in their shoes: recognising the expression of empathy as a research reality. Emotion, Space and Society 5(2):103-112. http://dx.doi.org/10.1016/j.emospa.2010.10.007

Joseph, G. M., C. LeGrand, and R. D. Salvatore, editors. 1998. Close encounters of empire: writing the cultural history of U.S.Latin American relations. Duke University Press, Durham, North Carolina, USA. http://dx.doi.org/10.1215/9780822396352 
Kesby, M. 2007. Spatialising participatory approaches: the contribution of geography to a mature debate. Environment and Planning A 39(12):2813-2831.

Knight, A. T. 2013. Reframing the theory of hope in conservation science. Conservation Letters 6(6):389-390. http://dx.doi. org/10.1111/conl.12078

Knight, A. T., R. M. Cowling, M. Rouget, A. Balmford, A. T. Lombard, and B. M. Campbell. 2008. Knowing but not doing: selecting priority conservation areas and the researchimplementation gap. Conservation Biology 22(3):610-617. http:// dx.doi.org/10.1111/j.1523-1739.2008.00914.x

Kohler, R. E. 2002. Place and practice in field biology. History of Science 40(2):189-210. http://dx.doi.org/10.1177/007327530204000204

Laird, S. A., and E. E. Lisinge. 2002. Protected area research policies: developing a basis for equity and accountability. Pages 127-176 in S. A. Laird, editor. Biodiversity and traditional knowledge: equitable partnerships in practice. Earthscan, London, UK.

Lang, D. J., A. Wiek, M. Bergmann, M. Stauffacher, P. Martens, P. Moll, M. Swilling, and C. J. Thomas. 2012. Transdisciplinary research in sustainability science: practice, principles, and challenges. Sustainability Science 7(S1):25-43. http://dx.doi. org/10.1007/s11625-011-0149-X

Lara, K. I. 2003. Vamos de cacería: el acceso al espacio y la distribución de la carne de monte en las comunidadas Tacana de Tumupasha y San Silvestre. Thesis. Universidad de la Cordillera, La Paz, Bolivia.

Latour, B. 1987. Science in action: how to follow scientists and engineers through society. Harvard University Press, Cambridge, Massachusetts, USA.

Latour, B. 1999. Pandora's hope: essays on the reality of science studies. Harvard University Press, Cambridge, Massachusetts, USA.

Latour, B., and S. Woolgar. 1979. Laboratory life: the construction of scientific facts. Sage, Beverly Hills, USA.

Lefebrve, H. 1991. The production of space. Blackwell, Oxford, UK.

Lehm, Z., H. Salas, E. Salinas, I. Gomez, and K. Lara. 2002. Diagnóstico de actores sociales PNANMI-Madidi. WCS/CARE, La Paz, Bolivia.

Livingstone, D. N. 1995. The spaces of knowledge: contributions towards a historical geography of science. Environment and Planning D 13(1):5-34. http://dx.doi.org/10.1068/d130005

Livingstone, D. N. 2003. Putting science in its place: geographies of scientific knowledge. University of Chicago Press, Chicago, Illinois, USA. http://dx.doi.org/10.7208/chicago/9780226487243.001.0001

Lorimer, J. 2008. Counting corncrakes: the affective science of the UK corncrake census. Social Studies of Science 38(3):377-405. http://dx.doi.org/10.1177/0306312707084396

Louis, R. P. 2007. Can you hear us now? Voices from the margin: using indigenous methodologies in geographic research.
Geographical Research 45(2):130-139. http://dx.doi.org/10.1111/ j.1745-5871.2007.00443.x

Lowe, C. 2004. Making the monkey: how the Togean macaque went from "new form" to "endemic species" in Indonesians' conservation biology. Cultural Anthropology 19(4):491-516. http://dx.doi.org/10.1525/can.2004.19.4.491

Mayer, E., and R. Bolton. 1977. Andean kinship and marriage. American Anthropological Association, Washington, D.C., USA.

McGregor, D. 2004. Coming full circle: Indigenous knowledge, environment, and our future. American Indian Quarterly 28 (3-4):385-410. http://dx.doi.org/10.1353/aiq.2004.0101

Meine, C. 2010. Conservation biology: past and present. Pages 7-26 in N. S. Sodhi and P. R. Ehrlich, editors. Conservation biology for all. Oxford University Press, Oxford, UK.

Milner-Gulland, E. J., M. Fisher, S. Browne, K. H. Redford, M. Spencer, and W. J. Sutherland. 2010. Do we need to develop a more relevant conservation literature? Oryx 44(1):1-2. http://dx. doi.org/10.1017/S0030605309991001

Mistry, J., A. Berardi, and M. Simpson. 2009. Critical reflections on practice: the changing roles of three physical geographers carrying out research in a developing country. Area 41(1):82-93. http://dx.doi.org/10.1111/j.1475-4762.2008.00841.x

Mohan, G. 2001. Beyond participation: strategies for deeper empowerment. Pages 153-167 in B. Cooke, and U. Kothari, editors. Participation: the new tyranny? Zed Books, London, UK.

Moon, K., and D. Blackman. 2014. A guide to understanding social science research for natural scientists. Conservation Biology 28(5):1167-1177. http://dx.doi.org/10.1111/cobi.12326

Nadasdy, P. 2003. Reevaluating the co-management success story. Arctic 56(4):367-380. http://dx.doi.org/10.14430/arctic634

Nielsen, J. Ø., and S. A. L. D'haen. 2014. Asking about climate change: reflections on methodology in qualitative climate change research published in Global Environmental Change since 2000. Global Environmental Change 24:402-409. http://dx.doi. org/10.1016/j.gloenvcha.2013.10.006

Nielsen, M. R., and J. F. Lund. 2012. Seeing white elephants? The production and communication of information in a locally-based monitoring system in Tanzania. Conservation and Society 10 (1):1-14. http://dx.doi.org/10.4103/0972-4923.92188

Nowotny, H., P. Scott, and M. Gibbons. 2006. Re-thinking science: knowledge and the public in an age of uncertainty. Polity, Oxford, UK.

Pain, R. 2004. Social geography: participatory research. Progress in Human Geography 28(5):652-663. http://dx.doi. org/10.1191/0309132504ph511pr

Pain, R. 2014. Impact: striking a blow or walking together? ACME: An International E-Journal for Critical Geographies 13 (1):19-23. [online] URL: http://ojs.unbc.ca/index.php/acme/ article/view/986/840

Pain, R., and P. Francis. 2003. Reflections on participatory research. Area 35(1):46-54. http://dx.doi.org/10.1111/1475-4762.00109 
Pain, R., M. Kesby, and K. Askins. 2011. Geographies of impact: power, participation and potential. Area 43(2):183-188. http://dx. doi.org/10.1111/j.1475-4762.2010.00978.x

Platteau, J.-P. 2004. Monitoring elite capture in communitydriven development. Development and Change 35(2):223-246. http://dx.doi.org/10.1111/j.1467-7660.2004.00350.x

Pratt, M. L. 1992. Imperial eyes: travel writing and transculturation. Routledge, London, UK.

Pullin, A. S., and T. M. Knight. 2009. Doing more good than harm - building an evidence-base for conservation and environmental management. Biological Conservation 142 (5):931-934. http://dx.doi.org/10.1016/j.biocon.2009.01.010

Raffles, H. 2002. In Amazonia: a natural history. Princeton University Press, Princeton, New Jersey, USA.

Rigney, L. H. 2001. A first perspective of indigenous Australian participation in science: framing indigenous research towards indigenous Australian intellectual sovereignty. Kaurna Higher Education Journal 7:1-13.

Robbins, P. 2006. Research is theft: environmental inquiry in a postcolonial world. Pages 311-324 in S. C. Aitken and G. Valentine, editors. Approaches to human geography: philosophies, theories, people and practices. Sage, London, UK.

Routledge, P. 1996. The third space as critical engagement. Antipode 28(4):399-419. http://dx.doi.org/10.1111/j.1467-8330.1996. tb00533.x

Roux, D. J., K. H. Rogers, H. C. Biggs, P. J. Ashton, and A. Sergeant. 2006. Bridging the science-management divide: moving from unidirectional knowledge transfer to knowledge interfacing and sharing. Ecology and Society 11(1):4. [online] URL: http:// www.ecologyandsociety.org/vol11/iss1/art4/

Scott, J. C. 1985. Weapons of the weak: everyday forms of peasant resistance. Yale University Press, New Haven, Connecticut, USA.

Scott, J. C. 1990. Domination and the art of resistance: hidden transcripts. Yale University Press, New Haven, Connecticut, USA.

SERNAP (Servicio Nacional de Areas Protegidas). 2006. Parque Nacional y Area Natural de Manejo Integrado Madidi: plan de manejo. Servicio Nacional de Areas Protegidas, La Paz, Bolivia.

Shanley, P., and S. A. Laird. 2002. 'Giving back': making research results relevant to local groups and conservation. Pages 102-124 in S. A. Laird, editor. Biodiversity and traditional knowledge: equitable partnerships in practice. Earthscan, London, UK.

Shapin, S. 1990. Science and the public. Pages 990-1007 in R. C. Olby, G. N. Cantor, J. R. R. Christie, and M. J. S. Hodge, editors. Companion to the history of modern science. Routledge, London, UK.

Sharpe, B. 1998. 'First the forest': conservation, 'community' and 'participation' in south-west Cameroon. Journal of the International African Institute 68(1):25-45. http://www.jstor.org/ $\underline{\text { stable/1161146 }}$

Shirk, J. L., H. L. Ballard, C. C. Wilderman, T. Phillips, A. Wiggins, R. Jordan, E. McCallie, M. Minarchek, B. V.
Lewenstein, M. E. Krasny, and R. Bonney. 2012. Public participation in scientific research: a framework for deliberate design. Ecology and Society 17(2):29. http://dx.doi.org/10.5751/ ES-04705-170229

Silva, R., D. Robison, S. McKean, and P. Álvarez. 2002. La historia de la ocupación del espacio y el uso de los recursos en el PNANMI Madidi y su zona de influencia. CARE-WCSAgroecología Bosque y Selva, Rurrenabaque, Bolivia.

Smith, L. T. 1999. Decolonizing methodologies: research and indigenous peoples. Zed Books, London, UK.

Soulé, M. E. 1985. What is conservation biology?: A new synthetic discipline addresses the dynamics and problems of perturbed species, communities, and ecosystems. BioScience 35(11):727-734. http://dx.doi.org/10.2307/1310054

Spivak, G. C. 1988. Can the subaltern speak? Pages 271-313 in C. Nelson and L. Grossberg, editors. Marxism and the interpretation of culture. University of Illinois Press, Chicago, Illinois, USA.

Sundberg, J. 2006. Conservation encounters: transculturation in the 'contact zones' of empire. Cultural Geographies 13(2):239-265. http://dx.doi.org/10.1191/1474474005eu337oa

Sutherland, W. J., A. S. Pullin, P. M. Dolman, and T. M. Knight. 2004. The need for evidence-based conservation. Trends in Ecology and Evolution 19(6):305-308. http://dx.doi.org/10.1016/j. tree.2004.03.018

Terborgh, J. 2004. Reflections of a scientist on the World Parks Congress. Conservation Biology 18(3):619-620. http://dx.doi. org/10.1111/j.1523-1739.2004.01837.x

Torre, M. E. 2010. The history and enactments of contact in social psychology. Dissertation. City University of New York, New York, New York, USA.

Torre, M. E., M. Fine, N. Alexander, A. B. Billups, Y. Blanding, E. Genao, E. Marboe, T. Salah, and K. Urdang. 2008. Participatory action research in the contact zone. Pages 23-44 in J. Cammarota and M. Fine, editors. Revolutionizing education: youth participatory action research in motion. Routledge, New York, New York, USA.

Tsing, A. L. 2005. Friction: an ethnography of global connection. Princeton University Press, Princeton, New Jersey, USA.

Valentine, G. 2008. Living with difference: reflections on geographies of encounter. Progress in Human Geography 32 (3):323-337. http://dx.doi.org/10.1177/0309133308089372

van Kerkhoff, L. E., and L. Lebel. 2015. Coproductive capacities: rethinking science-governance relations in a diverse world. Ecology and Society 20(1):14. http://dx.doi.org/10.5751/ es-07188-200114

Verran, H. 2002. A postcolonial moment in science studies: alternative firing regimes of environmental scientists and aboriginal landowners. Social Studies of Science 32(5-6):729-762. http://dx.doi.org/10.1177/030631270203200506

von Heland, F., B. Crona, and P. Fidelman. 2014. Mediating science and action across multiple boundaries in the Coral Triangle. Global Environmental Change 29:53-64. http://dx.doi. org/10.1016/j.gloenvcha.2014.08.003 
Walsh, C. 2012. "Other" knowledges, "other" critiques: reflections on the politics and practices of philosophy and decoloniality in the "other" America. Transmodernity: Journal of Peripheral Cultural Production of the Luso-Hispanic World 1 (3):11-27. [online] URL: http://escholarship.org/uc/item/6qd721cp

Walsh, J. C., L. V. Dicks, and W. J. Sutherland. 2015. The effect of scientific evidence on conservation practitioners' management decisions. Conservation Biology 29(1):88-98. http://dx.doi. org/10.1111/cobi.12370

Walter, M. 2005. Using the 'power of the data' within Indigenous research practice. Australian Aboriginal Studies 2005(2):27-34.

WCS (Wildlife Conservation Society). 2012. WCS, Bolivian Park Service (SERNAP), and other groups chronicle staggering diversity of Bolivia's Madidi National Park. Press release. WCS, Bronx, New York, USA. [online] URL: http://newsroom.wcs.org/NewsReleases/articleType/ArticleView/articleId/6143/WCS-Bolivian-ParkService-SERNAP-and-Other-Groups-Chronicle-Staggering-Diversityof-Bolivias-Madidi-National-Park.aspx

Weichselgartner, J., and R. Kasperson. 2010. Barriers in the science-policy-practice interface: toward a knowledge-actionsystem in global environmental change research. Global Environmental Change 20(2):266-277. http://dx.doi.org/10.1016/ j.gloenvcha.2009.11.006

Whitmarsh, L., G. Seyfang, and S. O’Neill. 2011. Public engagement with carbon and climate change: To what extent is the public 'carbon capable'? Global Environmental Change 21 (1):56-65. http://dx.doi.org/10.1016/i.gloenvcha.2010.07.011

Whittle, R., M. Walker, and W. Medd. 2011. Suitcases, storyboards and Newsround: exploring impact and dissemination in Hull. Area 43(4):477-487. http://dx.doi.org/10.1111/

j.1475-4762.2011.01025.x 


\section{Appendix 1: Additional details of quantitative assessment of previous research in Madidi}

As there were no organized records available previous to 2004 , the analysis was limited to the 10-year period between 2004-2013. A total of 88 research projects were identified (excluding the research described in this paper), of which 3 were immediately excluded from analysis because they were determined to be government-led evaluations that did not have research as the primary aim (i.e. hydrological measurement, monitoring). Of the remaining projects, $46 \%$ were led by principal investigators based at foreign institutions and 54\% were Bolivian-based. For all other projects the following information was recorded (to the extent that it was available): principal investigator(s), institution, type of study, years carried out, title of project, subject, geographical location, research objectives and contact information of the PIs. Contact details for the principal investigators was able to be found for 75 of the projects, who were then contacted either in person, by telephone or via email. Of these contact attempts, 15 went unanswered, one person explicitly refused to answer the questions, 11 responded that the study in question was not carried out in Madidi due to permitting problems or other issues, and nine responded by email but didn't complete the questions. Over a one-year period (between December 2013-November 2014) I then attempted to follow up with the principal investigator(s) listed on each project to verify the information obtained and ask additional questions about the level of local involvement in the project, potential implications for management and extent to which the research results were disseminated and/or published. For the remaining 40 studies, complete information was obtained directly from the principal investigator and the data presented are based on this subsample of projects. 


\section{Appendix 2: Additional details on methodology}

The research described in this paper is based on an applied methodology with an action research component, and was undertaken as part of a PhD based at the Lancaster Environmental Centre at Lancaster University. The fieldwork was carried out during four key periods in Bolivia, including a reconnaissance visit January-February of 2012 (one month), a preliminary fieldwork period June-December of 2012 (six months), a main fieldwork stage May-December 2013 (6.5 months), and a period of validation of data/preliminary dissemination stage June-August in 2014 ( 2 months), which included some documentary filming of interviews previously conducted. A final dissemination stage was carried out between September-November of 2015 with a large percentage of the involved participants/actors mentioned in the research.

\section{Interviews and participant observation}

Unstructured and semi-structured interviews were carried out with researchers $(n=24)$, local leaders and community members $(n=42)$, park guards and administrators $(n=27)$, and staff of government ministries and/or other conservation NGOs $(n=9)$. An additional 35 interviews were conducted in 2012 in the Takana 1 indigenous territory with local people who had been involved in a hunter/fisher self-monitoring project. Interviews were focused on understanding the main issues involved with scientific research and the management of natural resources in the Madidi region, specifically regarding experiences with park management, main concerns of community regarding conservation activities in the region, and awareness of existing scientific research and monitoring. Most interviews lasted between 20-40 minutes, but some discussions with key individuals continued over many hours or even days due to close proximity. Other interviews were conducted very briefly (15 minutes) to ask about a person's specific perception of a given situation or project. The latter was especially the case for the interviews conducted with Takana and Tsimane'-Mosetén hunters and fishers who had previously participated in self-monitoring projects with the Wildlife Conservation Society. Questions focused on how decisions about natural resources use are made at local, regional and national levels, the role of scientific research in those decisions, micro and macro-level politics and encounters around the production and dissemination of scientific research. See Appendix B. Some of these interviews were also repeated and filmed in 2014, and two short documentaries were created as a result, Bolivian Perspectives on Research, and the Park Guards of Madidi.

Alongside interviews, I used participant observation to better understand the regional context as well as the daily activities of protected area staff, researchers, and local community members. Particular focus was directed at two different areas: 1) the ranger-based integral monitoring programme, run by the National Service of Protected Areas with technical support from the Wildlife Conservation Society (WCS) in Bolivia; and 2) interactions in the field through wider projects between conservation science / biological research institutions (Wildlife Conservation Society Bolivia, Conservation International) and leadership councils and communities of indigenous territories in region (Takana, Lecos de Apolo, San Jose de Uchupiamonas and Tsimane'-Moseten). In addition, on several occasions I accompanied researchers (both social and natural 
scientists) on trips, workshops and social encounters in local communities in protected areas and bufferzone.

\section{Workshops}

Workshops were carried out with three stakeholder groups - park guards, indigenous communities, and scientists. In the case of the park guards, the workshops were structured in part around the systematic analysis of past research conducted in the protected area. The main aim was to discuss what had been done previously and to what extent those studies had been disseminated/ implemented for management, and in the case of Madidi, to develop a specific regulation for research in the protected area. A total of 30 park guards from Madidi and Pilón Lajas participated in 3 workshops in 2013.

Workshops were also held in two 'over-researched' indigenous communities, and were organized around a proposal to create a community norm to negotiate their relations with researchers in the future (i.e. ethical protocols). Between 2014-2015 these norms were revisited with local leaders, and although they were said to provide a 'reference' for the communities with regards to research, their usefulness was very limited. A more effective approach would be longer-term and community-led, but this was not possible due to the time and budgetary constraints of the $\mathrm{PhD}$, in addition to the fact that the communities had much more pressing issues to deal with at the time.

Two 'communication and dissemination training' workshops were also held with students and staff of the National Herbarium (a botanical institute) in La Paz. These were developed and carried out by request of the Herbarium's director, and attended by $40+$ participants. Activities included individual and collective reflection, role play and group discussion. Between December of 2012 and August of 2014 feedback sessions were held with: Madidi NP/NAIM, a group of Bolivian researchers from various institutions, and the Takana, San Jóse de Uchupiamonas, and Tsimane'-Mosetén indigenous councils. Additional meetings to present findings and materials were held with the Wildlife Conservation Society, Pilón Lajas BR/IT, SERNAP, and the Vice-Ministry of the Environment's Department of Biodiversity. 


\section{Appendix 3: Sample interview schedule with park guards}

Relationships with scientists and researchers:

1. Do many researchers come to the park? What do they do? Do they always come by the central office? Do they ask the park guards for help (if so what kind)?

2. Have you had any experience working with or helping scientists or researchers in the park? What were they doing? What was your role (guide, informant, etc.?)

3. How was the experience for you? What did you learn?

Perceptions of researchers and how researchers act around local people

1. Do the researchers that come involve the local communities in any way? How? (as guides, interpreters, etc.)?

2. How do you think local people perceive researchers?

3. How do researchers treat local people?

Perceptions of what research is for

1. Do you think research is important?

2. Why? What does it provide?

3. Do researchers disseminate locally the results of their work?

4. Do research results help to inform or influence the management of the protected area? If not, why do you think that might be? If yes, how? (Ask for examples)

Processes of disseminating and communicating information in the protected area

1. How is information communicated between the park staff and the local population?

2. If there are results from a research project that would be important for local communities to know about (for example, the environmental impacts of constructing a road through the park), how would that information be communicated? Is there a process in place, or would one need to be created?

3. Do you believe it's important to disseminate technical information to local communities? Why or why not?

4. How do you think local people could be more involved in scientific research?

Ideas for future research

1. What types of research studies are lacking in the region?

2. What information does the park need to improve management and support conservation?

3. How do you think research could further support conservation in the region?

4. What would have to be improved or change in order to achieve that? 


\begin{tabular}{|c|c|c|}
\hline $\begin{array}{l}\text { Source } \\
\text { Number }\end{array}$ & Date & $\begin{array}{l}\text { Type of interview/source (and full name of interviewee if } \\
\text { name was requested to be mentioned) }\end{array}$ \\
\hline 1 & $\begin{array}{l}\text { November } \\
2012\end{array}$ & Unstructured interview with indigenous leader \\
\hline 2 & $\begin{array}{l}\text { December } \\
2013\end{array}$ & $\begin{array}{l}\text { Unstructured interview with scientists working in the Madidi } \\
\text { region }\end{array}$ \\
\hline 3 & $\begin{array}{l}\text { October } \\
2013\end{array}$ & $\begin{array}{l}\text { Semi-structured interview with Cesar Bascope, Madidi park } \\
\text { guard }\end{array}$ \\
\hline 4 & July 2014 & $\begin{array}{l}\text { Video interview with Celín Quenevo, ex-president of Takana } \\
\text { nation }\end{array}$ \\
\hline 5 & July 2014 & $\begin{array}{l}\text { Video interview with Ebelio Romay, ex-park guard of } \\
\text { Madidi NP/NAIM and part of technical team for the } \\
\text { Tsimané-Mosetén indigenous council }\end{array}$ \\
\hline 6 & July 2013 & Interview with researcher working in Madidi region \\
\hline 7 & $\begin{array}{l}\text { November } \\
2013\end{array}$ & Workshop with community of San José de Uchupiamonas \\
\hline 8 & $\begin{array}{l}\text { November } \\
2013\end{array}$ & $\begin{array}{l}\text { Informal discussion with Hernan Nay, community member } \\
\text { of San Miguel }\end{array}$ \\
\hline 9 & $\begin{array}{l}\text { October } \\
2012\end{array}$ & $\begin{array}{l}\text { Unstructured interviews held with members of Mosetén } \\
\text { community of Asunción del Quiquibey }\end{array}$ \\
\hline 10 & $\begin{array}{l}\text { November } \\
2013\end{array}$ & $\begin{array}{l}\text { Unstructured interview with community member in San José } \\
\text { de Uchupiamonas }\end{array}$ \\
\hline 11 & $\begin{array}{l}\text { December } \\
2013\end{array}$ & $\begin{array}{l}\text { Feedback session with the Tsimané-Mosetén indigenous } \\
\text { council }\end{array}$ \\
\hline 12 & June 2013 & $\begin{array}{l}\text { Semi-structured interview with Mario Felipe Alvarez } \\
\text { Chaves, community member }\end{array}$ \\
\hline 13 & $\begin{array}{l}\text { October } \\
2013\end{array}$ & Semi-structured interview with Honorio Pariamo, local guide \\
\hline 14 & $\begin{array}{l}\text { October } \\
2013\end{array}$ & $\begin{array}{l}\text { Semi-structured interview with Richard Cuevas and Ramiro } \\
\text { Cuevas, local guides }\end{array}$ \\
\hline 15 & August 2013 & Workshop with botanists from the National Herbarium \\
\hline 16 & $\begin{array}{l}\text { November } \\
2013, \text { July } \\
2014\end{array}$ & $\begin{array}{l}\text { Unstructured interviews with community members of San } \\
\text { Jose de Uchupiamonas }\end{array}$ \\
\hline 17 & $\begin{array}{l}\text { September } \\
2012\end{array}$ & $\begin{array}{l}\text { Semi-structured interviews with hunters and fishers in } \\
\text { Takana } 1 \text { territory along the Beni river }\end{array}$ \\
\hline 18 & July 2014 & $\begin{array}{l}\text { Workshop with community of San Miguel, Takana } 1 \\
\text { territory }\end{array}$ \\
\hline 19 & $\begin{array}{l}\text { November } \\
2012\end{array}$ & $\begin{array}{l}\text { Semi-structured interview with Guido Mamani, president of } \\
\text { the San Jose de Uchupiamonas indigenous territory }\end{array}$ \\
\hline 20 & August 2014 & $\begin{array}{l}\text { Unstructured interview with biologist, Maria Eugenia Copa } \\
\text { Alvaro }\end{array}$ \\
\hline 21 & June 2013 & $\begin{array}{l}\text { Semi-structured interview with Juan Ortiz, Madidi park } \\
\text { guard }\end{array}$ \\
\hline 22 & July 2014 & Video interview with Clemente Caimani, ex-president of the \\
\hline
\end{tabular}




\begin{tabular}{|l|l|l|}
\hline & & Tsimané-Mosetén indigenous council \\
\hline 23 & $\begin{array}{l}\text { October } \\
2013\end{array}$ & $\begin{array}{l}\text { Semi-structured interview with Remberto Chivapuri, Madidi } \\
\text { park guard }\end{array}$ \\
\hline 24 & $\begin{array}{l}\text { December } \\
2013\end{array}$ & $\begin{array}{l}\text { Semi-structured interview with Lilian Painter, director of the } \\
\text { Bolivian office for the Wildlife Conservation Society }\end{array}$ \\
\hline 25 & $\begin{array}{l}\text { November } \\
2013\end{array}$ & Workshop with park guards from Pilón Lajas \\
\hline 26 & $\begin{array}{l}\text { September } \\
2012\end{array}$ & $\begin{array}{l}\text { Semi-structured interview with Eduardo Cavinas, community } \\
\text { member of Cachichira }\end{array}$ \\
\hline
\end{tabular}

